\title{
Can Informative Traffic Signs Also Be Obligatory? Polish Constitutional Tribunal and Supreme Court Versus Traffic Signs
}

\author{
Michał Dudek ${ }^{1}$ (D)
}

Published online: 23 January 2018

(C) The Author(s) 2018. This article is an open access publication

\begin{abstract}
This article discusses a rare instance of the highest national courts explicitly addressing traffic signs in their judgments or decisions. It critically examines the standpoint expressed by the Polish Constitutional Tribunal and the Supreme Court, according to which the basic traffic sign categories in Polandobligatory, prohibitory, informative and warning - are not separable (not disjunctive) [e.g. prima facie non-normative signs (informative or warning) can also be normative (obligatory or prohibitory)]. These courts formulated this idea when addressing the legal question concerning the applicability of legal provision penalizing failure to comply with a traffic sign to parking a car without paying a fee in an area marked by an informative sign that indicates the need to charge a fee for parking. The article analyses and criticizes the relevant standpoint of the Polish Constitutional Tribunal and the Supreme Court. It shows how many negative consequences can result from frivolous treatment and neglect of traffic signs. It also reconstructs some possible practical recommendations concerning not only traffic signs but also visualizations of legal rules in general.
\end{abstract}

Keywords Legal theory · Traffic signs · Visualization of law · Interpretation of law

Michał Dudek

michal.dudek@uj.edu.pl

1 Department of Sociology of Law, Faculty of Law and Administration, Jagiellonian University in Krakow, Bracka 12, Room 214, 31-005 Kraków, Poland 


\section{Introduction}

Although the issue of traffic signs-perhaps the most explicit example of visuality of law-gains noticeable but definitely still not widespread attention from broadly understood legal scholars, ${ }^{1}$ one can venture to say that the instances of addressing the issue in a direct way, or even interpreting traffic signs by the judiciary, including the highest courts in the national court hierarchy, seem to be even rarer. This relatively short and concise article analyses one particular instance of such an uncommon confrontation of the highest courts with a rather mundane, but only seemingly trivial aspect of legal order: traffic signs. It critically examines especially the standpoint expressed by the Polish Constitutional Tribunal and the Supreme Court concerning traffic signs, according to which the basic traffic sign categories in Poland-obligatory, prohibitory, informative and warning ${ }^{2}$ - are not separable (not disjunctive) in the sense that, for instance, prima facie non-normative signs (informative or warning) can also be normative (obligatory or prohibitory).

Of course, not only from the pragmatics-informed, but perhaps also from the much more everyday, commonsensical perspective the mentioned categories of traffic signs are only conventional. Accordingly, there are no traffic signs which are only obligatory, only prohibitory, only informative or only warning. "Obligatory", "prohibitory", "informative" and "warning" are nothing more than labels, or, to put it differently, aspects with which one can characterize particular signs. Adopting this general approach, one can say, for instance, that given sign is warning, informative and obligatory simultaneously, while different sign can be described as predominantly informative, but with some noticeable prohibitory aspect. One can even look similarly at the more general categories of normative and non-normative traffic signs and argue that normativity and non-normativity is not a strict division (either/or). Some traffic signs can be regarded as having more normativity than nonnormativity, vice versa, or even as having these two aspects specifically equalized.

\footnotetext{
${ }^{1}$ It seems that there are at least three categories of research on traffic signs conducted by legal scholars. First, one can distinguish mainly theoretical research, which takes into account a variety of perspectives, including semiotic, communication, linguistic, logical, social or cultural, to name just a few of them [e.g. $6,8,21,32,35]$. The second kind of research concerns the more practically-oriented issues of traffic organization and planning, but is still theoretically relevant [e.g. 17-20]. The last category of research is focused on various road traffic regulations and is basically a kind of legal dogmatics [e.g. 14: 288-357]. The presented article fits mainly into the first category.

2 Obligatory signs are mostly circular (with one rectangular exception) with thin white borders, blue backgrounds and mostly white graphics on the background (with few exceptions with black and red elements). Prohibitory signs are much more complex. They are mostly circular (with rectangular or even octagonal exceptions) with red borders (some have thin black borders), white backgrounds (though occasionally blue) and black graphics on the background (with some red, yellow and blue exceptions and even captions in black or white letters). It should be stressed that this list of features still does not cover them completely. Informative signs are similarly complex. They are mostly rectangular (with some square exceptions and size or angle modifications) with thin white borders (but some are black), blue backgrounds (though there are some with white backgrounds) and white, black, red or even green graphics on the background, not to mention black or white captions. Just as in the case of prohibitory signs, this description of informative signs is still far from being comprehensive. Warning signs are much simpler in turn. They are triangular (equilateral) with red borders, yellow backgrounds and mostly black graphics on the background (there are two exceptions with white, red and green elements). One of their vertices faces up, with the exception of the yield sign, for which one of the vertices faces down.
} 
Despite recognizing this possible perspective at the rather common traffic sign categories, it should be stressed that this article's point of departure and, in fact, object of interest is opposite. Namely, when a specific valid legal act explicitly introduces and in fact stresses different categories of given regulatory instrumentsas in the case of traffic regulations and legal categorization of traffic signs into relevant basic four categories-one can say that from the legal, or even jurisprudential perspective one should simply treat them as actually separate (disjunctive), even if it seems artificial, or even counterfactual from more pragmatically-oriented standpoint. As will be shown hereinafter, there are many important reasons-also such referring to the interests and needs of ordinary people-to stick to and actually respect separability of explicit legal categories, including distinction of obligatory, prohibitory, informative and warning traffic signs. From perspective of these reasons it is especially puzzling that one of the most important institutions supposed to follow and protect this suggested strict legal perspective (or "logic") — the Polish Constitutional Tribunal and the Supreme Court — can be seen as actually opposing it by saying that four basic traffic sign categories are not disjunctive, even though this categorization is explicit in relevant valid legal acts and its underestimation can lead to various controversies, also those clearly negative for law's addressees, which are discussed in this article. In the light of these reservations, it should be quite clear that the article specifically prioritizes the legal perspective over a pragmatic view of the categories of traffic signs, but this does not mean that the latter is completely ignored in the following argumentation.

Naturally, although some may regard the subject of this article as very particular, local and significant only for Polish legal order, it should be stressed at the beginning that Poland is, like many other countries, a follower of the Vienna Convention on Road Signs and Signals from 1968. ${ }^{3}$ On this ground, it cannot be ruled out that similar standpoint concerning traffic signs or some other problems directly or indirectly connected with this thesis or traffic signs in general, which are discussed hereinafter, are not or will not be relevant in the context of other national jurisdictions. Moreover, the ambition of this article is not only to analyse and criticize one particular thesis expressed by the highest courts in the Polish judiciary, but also to try to propose some positive recommendations concerning traffic signs as well as efforts to visualize any other non-road-traffic-related legal rules. ${ }^{4}$ These aims can be safely regarded as significant in a nearly universal way, outside of any national peculiarities and differences.

The structure of the article is as follows. The next section (Presentation) is devoted to the presentation of the situation, in which the standpoint of the Polish Constitutional Tribunal and the Supreme Court was expressed, which can be called the inseparability thesis. ${ }^{5}$ Before assessing this general standpoint in the fourth section (The Inseparability Thesis), the third section (Between the Visual and the

\footnotetext{
3 The text of Convention, amendments, other relevant documents and list of contracting parties are available at [34].

4 As examples of visualizations of non-road-traffic-related legal rules that show how diverse they can be, see $[2,4,16]$ or design shown in [7: 56], which is a preview of project in preparation.

5 Of course, it should not be associated with any other inseparability thesis one can come across in different disciplines, like, for instance, positivist legal philosophy.
} 
Text about the Visual) addresses a critique of one specific argument used by the Polish Constitutional Tribunal and the Supreme Court in the relevant situation, a critique provided by one of its commentators from Polish legal scholarship, which is also significant for the analysis of the aforementioned main thesis. Following from the previous presentation and analysis, the last section (A Positive out of a Negative) briefly reconstructs possible practical recommendations for the visualization of law, concerning traffic signs, as well as legal regulations other than laws on road traffic and the use of other, more or less complex means than simple pictograms and ideograms ${ }^{6}$ to visually represent them.

\section{Presentation}

The legal question that was addressed by the Polish Constitutional Tribunal and the Supreme Court and, in the end, led to the formulation of the inseparability thesis, concerns a very mundane activity: parking a car. It can be summed up as follows: is Article 92 paragraph 1 of the Polish Law of 20 May 1971-Code of Petty Offences-Journal of Laws 1997, no. 12, item 114, which states that "[w]hoever does not comply with the sign or traffic signal or a signal or command of the person authorized to direct traffic or to control traffic shall be subject to a fine or a reprimand" [24] applicable to parking a car without paying a fee in the area marked by informative sign D-44-a (paid) parking area?

Before providing the Polish Constitutional Tribunal's and the Supreme Court's answer to this question, one should say something more about the relevant Polish legal regulations. As stated earlier, in Polish legal order there are four basic categories of traffic signs-warning, prohibitory, obligatory and informative (to which the D-44 sign so crucial to this case belongs). This distinction is explicitly confirmed by Article 7 point 1 of the Polish Law of 20 June 1997-Road Traffic Law-Journal of Laws 1997, no. 98, item 602, which states that "[t]raffic signs and signals express warnings, prohibitions, orders or information" [23]. However, all legally valid Polish traffic signs and signals are subject to the separate Polish Regulation of Ministers of Infrastructure and Internal Affairs and Administration of 31 July 2002 on the traffic signs and signals-Journal of Laws 2002, no. 170, item 1393, which basically groups and presents how a given sign or signal looks and also includes their more or less detailed descriptions. At the time of proceedings of the Polish Constitutional Tribunal and the Supreme Court concerning, among other issues, the abovementioned question, the informative D-44 sign was described in the paragraph 58 point 4 of the Polish Regulation on the traffic signs and signals in the following way:

[s]ign D-44 "parking area" marks the entry into the zone where the parking of a vehicle is charged with a fee. In this zone it is forbidden to park a vehicle without paying the fee, with the exception of parking vehicles of persons or units for which a zero rate fee was set, as well as parking public transport

\footnotetext{
${ }^{6}$ On pictograms and ideograms in traffic signs see [11: 3506].
} 
vehicles at places designated for them. Sign D-45 "the end of the parking area" marks a departure from such zone [25]. ${ }^{7}$

On the one hand, Article 92 paragraph 1 of the Polish Code of Petty Offences is about, among other things, not complying with the traffic sign. The conformity or nonconformity to obligatory or prohibitory traffic signs is easy to comprehend, in comparison to the hypothetical conformity or nonconformity to warning or informative signs, the group to which the sign D-44 belongs. In the end, how can one comply with information, except that one simply becomes aware of what was communicated through a given medium? One can venture to say then that the mentioned Article 92 paragraph 1 of the Polish Code of Petty Offences can be applied only to nonconformity to such traffic signs that can be the subject of nonconformity, that is, obligatory or prohibitory, not warning or informative. However, the case of sign D-44 is not so easy as this sign's official classification as informative would suggest. Namely, its description in paragraph 58 point 4 of the Polish Regulation on the traffic signs and signals seems also to express a rather explicit prohibition in the following words: “(...) [i]n this zone it is forbidden to park a vehicle without paying the fee (...)". Having said that, the presented case stops being uninteresting and uninspiring as perhaps many regarded it at the beginning of this section.

In the face of the presented state of relevant legal regulations valid at the time and the particular problem concerning applicability of Article 92 paragraph 1 of the Polish Code of Petty Offences to not paying a fee for parking a car in an area marked by informative sign D-44, the Polish Constitutional Tribunal in its Judgment of 27 January 2004 (act sign. P 9/03) [22] and the Supreme Court in its Decision of 23 September 2009 (act sign. I KZP 15/09) [27] expressed, among other opinions and interpretations, the following standpoint: Article 92 paragraph 1 of the Polish Code of Petty Offences is in fact applicable to parking a car without paying a fee in an area marked by informative sign D-44. Also, both formulated two arguments in favour of this opinion. First, they noticed the already mentioned description of sign D-44 in paragraph 58 point 4 of the Polish Regulation on the traffic signs and signals and the prohibition of parking without paying included. As will be shown hereinafter, although there is a subtle yet significant controversy with the first argument, it could still be regarded as sufficient to justify the applicability of article 92 paragraph 1 of the Polish Code of Petty Offences to parking a car without paying a fee in an area marked by sign D-44. Nevertheless, the Polish Constitutional Tribunal and the Supreme Court decided to try to make their answer even more decisive and thus formulated a second, more general argument which can be reconstructed as follows: traffic signs of four basic categories (obligatory, prohibitory, informative and warning) are not separable, in the sense that, for

\footnotetext{
7 The D-44 sign is rectangular with a thin white border and background. In the background, there is a blue square of smoothed corners with a big white letter " $P$ " in its middle. Under the blue square with a "P", there is a caption in black letters that reads "Paid parking" with the indication of hours during which payment is required. The D-45 sign is rectangular with a thin white border and background. In the background, there is a grey square of smoothed corners with big white letter "P" in its middle. Under the grey "P" square, there is no caption. However, over the whole sign there is a red diagonal line, which crosses the sign from its top right to its bottom left corner.
} 
example, an informative sign can also fulfil an explicitly normative (obligatory or prohibitory) function, even if it is prima facie (according to the mentioned Polish Regulation on the traffic signs and signals) an informative sign only. This is the inseparability thesis and its rather modest genesis. Although it is the most explicit and eye-catching controversy here, one should address the argument concerning the prohibition included in the description of sign D-44 first, because it will be also useful for later investigation of the second argument.

\section{Between the Visual and the Text About the Visual}

As already suggested, the first argument only seemingly looks convincing. Naturally, one can stop at finding that the description of sign D-44 included a prohibition of parking without paying and arguing that this is the sufficient argument in favour of applicability of Article 92 paragraph 1 of the Polish Code of Petty Offences to it. On the other hand, one can and maybe even should think about this case more carefully and critically, as shown by one commentator of the abovementioned Decision of the Polish Supreme Court [31]. ${ }^{8}$ Ryszard A. Stefański basically argued that one should, in fact, distinguish the content of the sign and sign only (what the visual and the visual only tells) and the content of the description of the sign in the legal provision in some law or regulation (what the text tells about or in connection with the visual). Accordingly, there is a difference between complying with the sign and sign only (which is the proper subject of Article 92 paragraph 1 of the Polish Code of Petty Offences in the opinion of the mentioned commentator) and complying with some normative content expressed in the description of the sign in the legal act (which cannot be the subject of Article 92 paragraph 1 of the Polish Code of Petty Offences, because this Article is about complying with the sign and not some legal provision that describes it).

Leaving aside some important issues with this approach-more specifically, with the idea of the content of the sign and the sign only-like the problem of determination of that content or the existence of one true and fixed meaning of the visual, this possible perspective seems to have the following consequence for the discussed case: the applicability of Article 92 paragraph 1 of the Polish Code of Petty Offences to not paying for parking in an area marked by sign D-44according to the first argument - appears to be simply incorrect. In comparison to its description in paragraph 58 point 4 of the Polish Regulation on the traffic signs and signals (the text about the visual), it is controversial whether the content of the informative sign D-44 and this sign only (the visual) has some normative element (obligation or prohibition) that can be followed or broken and thus assessed according to Article 92 paragraph 1 of the Polish Code of Petty Offences.

\footnotetext{
${ }^{8}$ Compare also with previous standpoint of this author addressing the cited Polish Constitutional Tribunal's Judgment and opinions of legal scholars relevant to the case of sign D-44 and petty offences law [29: 25-26, 30: 404-405 and literature cited there]. The commented Polish Supreme Court's Decision raised significant interest, and there are other commentators on it beyond Stefański [e.g. 13, 33]. In turn, both the Polish Supreme Court's Decision and the Constitutional Tribunal's Judgment and also the interpretation of sign D-44 are addressed in [3: 762-766, 899].
} 
Both the Polish Constitutional Tribunal and the Supreme Court did not notice this subtlety. Accordingly, they argued for applicability of Article 92 paragraph 1 of the Polish Code of Petty Offences to not paying for parking in an area marked by sign D-44 on the basis of the prohibition included in paragraph 58 point 4 of the Polish Regulation on the traffic signs and signals. In this way, they privileged the text about the visual over the visual itself. It is not only controversial from the specific perspective of the distinction introduced in this section and its implications for interpretation of Article 92 paragraph 1 of the Polish Code of Petty Offences. In the end, if the Polish Constitutional Tribunal and the Supreme Court were so convinced about this particular solution, then their second argument-about inseparability of obligatory, prohibitory, informative and warning traffic signs-seems to be simply unnecessary. The first argument could be just enough to solve a case of parking a car without paying a fee in an area marked by sign D-44, naturally under the condition that one does not acknowledge the difference between what the visual and the visual only tells and what the text tells about or in connection with the visual. In the face of argumentation in both the Polish Constitutional Tribunal's Judgment and the Supreme Court's Decision, it seems justified to assume that these courts did not recognize this distinction, because they simply and most likely were not aware of it during their proceedings on the discussed case. Accordingly, the decision to introduce the second argument in favour of their solution can be regarded as nonunderstandable and, if not irrational, then definitely not thought through, especially when one learns about significant problems and controversies connected with it. The following section is devoted to their presentation.

\section{The Inseparability Thesis}

As has already been stated, both the Polish Constitutional Tribunal and the Supreme Court argued additionally that traffic signs of four basic categories (obligatory, prohibitory, informative and warning) are not separable. According to this inseparability thesis, an informative sign can also fulfil a normative (obligatory or prohibitory) function, even if it is prima facie an informative sign only (according to the mentioned Polish Regulation on the traffic signs and signals).

First of all, the advocacy for this thesis is not so easily understandable not only for a lawyer or legal scholar but most likely also for any person who actually participates in road traffic and has even the most basic comprehension of relevant law and traffic signs. In the end, one might ask a question: for what exactly then is the official distinction of obligatory, prohibitory, informative and warning traffic signs introduced in valid legal act if one says that traffic signs of these basic categories are in fact inseparable? This perfectly justified puzzlement was not the subject of any anticipatory response to it neither in the Polish Constitutional Tribunal's Judgment nor in the Supreme Court's Decision. Moreover, the thesis in question, formulated by the judiciary, undermines the actions of legislature concerning not some highly specialized areas of life, but everyday and common experience of participation in road traffic, whether as pedestrian or driver, for which clarity and universal readability of created regulations is crucial. The inseparability 
thesis seems to be detrimental to these important values. This consequence can be shown by trying to address the following question, which easily comes to mind in the face of the discussed standpoint: if one actually assumes that four basic categories of traffic signs in Poland are not separable, thus opposing what seems to directly and clearly follow from the mentioned Polish Regulation on the traffic signs and signals, then who or what decides that a traffic sign that is prima facie nonnormative (informative or warning) also fulfils a normative function (is obligatory or prohibitory) $?^{9}$ This question can be addressed with two possible answers.

First, one might argue that the description of the particular sign in the legal act decides whether the non-normative sign is in fact also normative. If the description of a given sign includes some normative elements, like prohibition or obligation, then this particular sign can be regarded as prohibitory or obligatory, even if its general classification in relevant legal regulation is different; that is, if it is an informative or warning sign. The discussed case of sign D-44 and its description in paragraph 58 point 4 of the Polish Regulation on the traffic signs and signals is a good illustration of this approach. It can be named as an approach of a strictly linguistically- or textually-oriented interpretation of sign.

This approach seems to be paradoxical not only because it specifically advocates that the way to comprehend a visual sign, like a traffic sign, is to analyse its verbal description. Moreover, and in a more practical everyday sense, it is directly connected with a significant risk of reducing readability of traffic signs for road traffic participants, for they will have to remember the descriptions of signs included in particular legal provisions in order to know how to act in a given situation. Although this approach does not seem to propose giving up on traffic signs, its adoption can lead to a situation in which traffic signs lose their attractiveness as quick, convenient and almost universally understandable means of regulating human activities. In the end, even the most seemingly basic traffic sign can become extremely complex through its verbal description. Accordingly, traffic participants will have to associate the given sign with its more or less elaborate and unintuitive, in comparison to the sign itself, description, which they should memorize. The approach of strictly linguistically- or textually-oriented interpretation of signs paradoxically seems to support the existence of traffic signs but at the same time deprives them of the positive features with which they are usually associated, most notably the possibility of relatively easy and correct ascription of meaning to them. Additionally, discussed answer to the question formulated earlier does not take it seriously, or it even simply obscures a rather important abovementioned difference between what the visual and the visual only tells and what the text tells about or in connection with the visual. This remark is quite obvious keeping in mind what was already said, but it is worth repeating because it seems that this lack of conceptual subtlety can be regarded as the common source of all suggested problems with the discussed approach.

\footnotetext{
9 Naturally, the non-normative function or content of normative signs is not problematic, because every prohibition or order can be regarded as also presupposing something non-normative, whether information or warning. This is the reason to focus on non-normative signs being also normative, even if the inseparability of categories of traffic signs can obviously go vice versa.
} 
The discussed question "Who or what decides that some prima facie nonnormative (informative or warning) traffic sign is also a normative one (obligatory or prohibitory), according to the inseparability thesis?" can naturally be addressed differently. As per the second answer, one might argue that some sort of functional reasoning about contents of signs from the perspective of their assumed goals allows one to determine whether some non-normative traffic sign is also normative. If, after focused analysis of a given sign and that sign only according to the hypothetical question "What is this sign for?", it proves to have some normative elements, like prohibition or obligation, or presupposes them, then this particular sign can be regarded as prohibitory or obligatory, even if its general classification in relevant legal regulation is different (informative or warning). This answer can be referred to as an approach of functionally-oriented interpretation.

In comparison to the first one, this approach-with its clear emphasis on the visual and not on the text about the visual-seems to take seriously the distinction of what the visual tells and what the text tells about or in connection with the visual. On this ground, its adoption will not lead to the same negative practical consequences concerning readability of traffic signs in the context of their legal descriptions. However, it has its own most probable problematic effects, and the question of what to do with or how to treat descriptions of traffic signs in relevant legal acts after adoption of this approach is only one of the less important of them. Namely, an approach of functionally-oriented interpretation can be questioned for significantly increasing the risk of undermining the legal certainty in its most basic sense as the possibility for law's addressees to correctly predict legal consequences of their own actions. ${ }^{10}$ In the end, if the meaning of traffic signs depends on interpretation focused only on those very signs, then one has to take into account situations in which there are significant differences, even disagreements, concerning the messages conveyed through particular traffic signs. In an extreme situation, one traffic sign can have as many mutually incoherent meanings as interpreters. Certainly, this is detrimental to the readability of traffic signs, but this time, in comparison to the critique of the first approach, it is in a way caused by signs themselves, or, to be more precise, by their interpretation, and not by their verbal descriptions in relevant legal acts. Also, as one can easily guess, the discussed second approach can facilitate the instrumentalization of law detrimental for the law's addressees. In the end, more careful analysis of the second approach can lead to imagining a certain scene. A police officer or traffic warden argues that some pedestrian did not comply with a given traffic sign, even if according not only to its interpretation by that pedestrian but also to the more common opinion about it, it seems that one simply cannot comply and cannot not comply with that sign, because it is only informative. Nevertheless, the police officer's or traffic warden's interpretation is different, and a fine is issued. Naturally, after adoption of the second approach, similar situations seem quite probable, unless a universally correct way of interpreting signs that will reduce the suggested subjective errors or deliberate manipulations is developed. However, this condition is problematic, to say the least, because it seems to be based on the already suggested controversial assumption that visuals can have one true and fixed meaning.

${ }^{10}$ On legal certainty see [1]. 
Moreover, even if one actually wants to adopt such an assumption notwithstanding controversy with its plausibility and, at the same time, advocates the inseparability thesis, a completely new problem seems to emerge. Namely, one believes in one true and fixed meaning of traffic signs but says that their meaning can, in fact, specifically go both ways: be non-normative and normative. There is then the problem of how to reconcile the inseparability thesis with the concept of one true and fixed meaning of traffic signs. Naturally, some can say that this problem is, in fact, only apparent. In the end, does the idea that each traffic sign actually has one right inherent sense really have to exclude the possibility of more complex meanings of a given sign, which are not simply either normative or non-normative, but a combination of both? Of course, this is not the place to carefully analyse this puzzle, nor to assess whether it is an actual puzzle in the first place. Nevertheless, it is presented here as just another way of showing the level of problems and controversies in which the inseparability thesis is entangled.

However, one who would think that the above list of issues is exhaustive would be wrong. Namely, there is at least one other problem with the inseparability thesis. To realize it, consider any non-normative traffic sign (informative or warning). Keeping in mind the discussed thesis, one can formulate the following questions. Can this sign fulfil a normative function (obligation or prohibition) that is not ascribed to or realized by any other sign in given legal order? Or maybe, can a nonnormative sign fulfil only such a normative function (obligation or prohibition) that is already ascribed to or fulfilled by some other sign (obligatory or prohibitory) in given legal order? If one answers to the first question in the affirmative, then a relevant non-normative sign in fact becomes a completely new normative sign. It orders or prohibits some action, which is not ordered or prohibited by any other traffic sign in given legal order. In the face of this, the inseparability thesis once again proves to be detrimental to the legal certainty and burdensome to the law's addressees. Depending on the already discussed two possible answers to the question "Who or what decides that some prima facie non-normative (informative or warning) traffic sign is also a normative one (obligatory or prohibitory)?", in order to recognize traffic signs, the law's addressees should either become very well-acquainted with their relevant official legal descriptions or somehow determine the correct, but often unintuitive functionally-oriented interpretation of traffic signs. In contrast, if one responds to the second question in the affirmative, then the relevant non-normative sign becomes an already existing normative sign. It orders or prohibits some action that is already ordered or prohibited by some other sign in a given legal order. It leads to the conclusion that the inseparability thesis can also cause the increase of redundancy ${ }^{11}$ of traffic signs in the very specific sense that, for example, two signs of basically two different categories are treated, due to their verbal legal descriptions or specific interpretations focused only on them, as if they communicate the very same thing. ${ }^{12}$ In effect, one can even expect an increase in

\footnotetext{
11 On broadly understood redundancy in law/legal texts, but without references to traffic signs or other graphics in them, see [9, 12].

12 Referring to the well-know Studnicki's [32: 152] traffic signs-related distinction of sign-types (images of particular traffic signs included in the text of relevant legal regulation) and sign-realizations (actual physical replications of sign-types placed in particular site in space), the noticed redundancy can be
} 
quantity of traffic signs, which would contribute to the visual pollution phenomenon. $^{13}$

However, it should be stressed that the increase of redundancy of traffic signs, in its suggested meaning of signs (sign-types) overlapping each other with respect to some realizable function and the increase of their quantity, can happen even if one does not adopt the inseparability thesis. In the end, the amount of traffic signs placed in a given area can be significantly high due to the actions of authorities who can be and who probably are completely oblivious to the discussed thesis. Similarly is in the case of discussed type of redundancy. Naturally, it should be acknowledged that the issue of traffic signs' redundancy seems to be much more complex than only one suggested kind of redundancy, and it should be addressed as a separate subject in a separate study. ${ }^{14}$ Nevertheless, the situation in which two different traffic signs (sign-types) seem to, in the end, realize the very same function, is possible independent of the inseparability thesis. Not to be groundless, consider as an example two Polish traffic signs-an informative D-3 and an obligatory C-5. ${ }^{15}$ The former is described in paragraph 44 point 1 of the Polish Regulation on the traffic signs and signals as follows: "[t]he sign D-3 'one-way street' marks the beginning or continuation of the road or the roadway on which traffic is handled in one direction". In turn, paragraph 35 point 1,5$)$ of the very same Regulation states that

\section{Footnote 12 continued}

named as sign-type-sign-type redundancy. This particular redundancy — probably the easiest way to imagine it is through the situation, in which two (or even more) different (e.g. one from informative and other from obligatory category) traffic signs (their types) in the end seem to convey the very same message — can be regarded as dangerous, and therefore requiring reduction or even complete elimination, because it can be instrumentalized in a negative way for a road traffic participant. Consider a situation similar to the one sketched above, when a given person has "failed to comply" with a given informative sign (its actual realization, but in the end based on sign-type), which is contentally convergent with a given normative sign-type (but its realization is absent in the place of action/omission of this person) and is tried to be brought to "justice" under the specific provisions.

13 On visual pollution see [28, 36].

14 However, as a preliminary proof of complexity of traffic signs' redundancy, next to rather controversial, because potentially abusive, sign-type-sign-type redundancy, already here one can tentatively distinguish other kinds of traffic signs' redundancy, which-in comparison with the one outlined in this study — can be regarded as neutral or even highly positive and functional [compare 5: 54, 10: 7, 15: 73]. In the end, one can analyze the relationship between the particular sign-realization (its content) and the environment in which it is placed and which it signifies. As sign-realizationenvironment redundancy one can classify situation when the referent of sign-realization is easily noticeable even without given sign or perhaps even when in the particular road environment there is the absence of element corresponding to the content of given sign-realization. On the other hand, it is not uncommon to see one particular sign-realization repeated few times on given part of the road. Naturally, this redundancy of few identical signs (sign-realizations) — which can be named simply sign-realizationsign-realization redundancy — can be regarded as functional and in fact necessary under possible lesser visibility conditions caused either by weather or other situational factors (e.g. truck at the front obscured a particular relevant sign-realization, but this sign is repeated several times on given section of the road, luckily for the driver behind this large vehicle). However, this easily understandable perspective of subjective informational needs of road traffic participants is not the only one relevant here, because signrealization-sign-realization redundancy is also entangled in much more objective issues, like economic calculation.

15 The D-3 sign is a square of smoothed corners with a thin white border and big white arrow facing up on a blue background. The C-5 sign is a circle, but the rest of its features are the same as D-3 - thin white border and big white arrow facing up on a blue background. 
"C-5 'straight ahead' (...) commit[s] to driving in the direction indicated by the arrow (...)". Are both of these signs in effect not obligating one to drive in the very same direction indicated by their arrows? ${ }^{16}$

Although the increase of the specific kind of redundancy and increase of quantity of traffic signs still can happen even without the adoption of inseparability thesis, this should not change its general assessment in light of the analyses above. It is extremely controversial and problematic, not only in a theoretical but also in a practical sense. Unfortunately, both authors of this thesis- the Polish Constitutional Tribunal and the Supreme Court in relevant Judgment and Decision-not only do not address these problems and controversies in any manner, but they seem to be completely oblivious to them. However, their carelessness is paradoxically a good, convincing and useful example of what can actually come out from not taking traffic signs seriously. Additionally, the discussed case not only illustrates consequences of neglecting specific yet ubiquitous part of law in everyday life, but it can also be used for even more practical goals. Namely, from the above negative discussion, one can draw some positive suggestions concerning not only traffic signs but visualizations of legal rules in general. These are briefly reconstructed in the following, last section of the article.

\section{A Positive out of a Negative}

On the one hand, when it comes to suggestions concerning traffic signs, it should not be surprising to anyone to demand that the separability of categories of traffic signs be upheld in the first place. Moreover, the above discussion seems to justify the postulate to reduce or remove overly extensive descriptions of given traffic signs, which can suggest different functions from the one actually resulting from their explicit ascription to some basic category, as in the case of the D-44 sign. In fact, its description was actually modified a few years after the Polish Constitutional Tribunal's Judgment and the Supreme Court's Decision. The Polish Regulation of Ministers of Transport, Construction and Maritime Economy and Internal Affairs of 3 October 2013 amending the Polish Regulation on the traffic signs and signalsJournal of Laws 2013, item 1325, changed the relevant paragraph 58 point 4. According to the amendment, "[s]ign D-44 'paid parking area' marks the entry into the zone where the parking of a car vehicle is charged with a fee. Sign D-45 'the end of the paid parking area' marks a departure from paid parking zone" [26]. However, it is up to discussion whether the presented change-mostly shortening of the description-is actually correct from the perspective of the above analyses, it seems to make even more convincing and pressing the next demand that follows them. In light of the discussed case, it seems reasonable to try to comprehensively re-analyse traffic signs in force in a given legal order (especially, non-normative signs) and, if needed, re-qualify them (for instance, informative into obligatory), in order to avoid

\footnotetext{
16 Kotowski [14: 313] seems to suggest the same problem. He says that the D-3 sign also has an explicitly normative character, but he does not compare it directly with any other sign, including the C-5 sign.
} 
ambiguities concerning their interpretation and to make separability of their categories even clearer. ${ }^{17}$ Keeping in mind the suggested complexity of redundancy of traffic signs, which needs to be addressed separately, during such a re-analysis it seems valuable to consider the reduction of one noticed kind of redundancy (signtype-sign-type redundancy). In the end, if two traffic signs of different categories seem to overlap each other and say basically the same thing, maybe one of them simply has to go?

On the other hand, and, finally, when it comes to suggestions concerning visualization of law in general (other than traffic signs), it seems that anyone who actually wants to visualize some rule should not include in its description anything that would go beyond what is actually visualized. Otherwise, this will most likely lead to a puzzling discrepancy similar to the D-44 sign and its original description, which can significantly undermine the clarity of the prepared visual and even the attractiveness of the whole idea of visualization of rules. Moreover, if one's ambitions are greater than the creation of visualization of a single rule and one wants to visualize many legal rules, there are at least two another suggestions reconstructable from the analyses above. First, if one decides to make some categories and distinctions in the body of visualized legal rules, one should simply stick to them. Second, if one visualizes many rules, then perhaps one should make sure that the prepared visualizations do not overlap each other in any higher degree than the redundancy already present in the legal domain to which visualized rules belong. The need to not repeat oneself is crucial when visualizing law, because, in the end, any visualization of a legal rule originally expressed verbally in a relevant legal act is already a specific repetition. The content of a text is represented through the medium of image. The two different channels convey or at least try to convey the very same message. From this basic perspective, the care for actual separability and avoiding redundancy (in the sense similar to the introduced sign-type-signtype redundancy) of prepared visualizations seems to be justified.

Although, as shown, it is possible to take some positive lesson out of a negative example, the gravity of controversies following from the discussed Polish Constitutional Tribunal's Judgment and the Supreme Court's Decision makes perfectly understandable a wish to finally take seriously the visualized legal rules, whether in the form of traffic signs or any others more or less complex. Otherwise, the emergence of other, even more serious problems than the ones discussed above, seems possible.

Acknowledgements The previous version of the article was presented at the International Workshop Deontic Drawings. Taking Graphic Rules Seriously, April 13, 2016, Cagliari, Italy. I would like to take the opportunity to thank the organizers, Prof. Giuseppe Lorini and Dr. Olimpia G. Loddo, as well as the other participants, especially Prof. Patrick Maynard and Prof. Stefano Moroni, for their inspiring comments. I would also like to thank the anonymous reviewers for careful reading of the original manuscript and offering important suggestions, which helped me to improve my argumentation. Naturally, this does not change the fact that only I am responsible for all of the possible substantive shortcomings of this article.

${ }^{17}$ Murat's [18: 37] distinction of proper informative signs (completely non-normative) and improper informative signs (also expressing some normativity, whether obligation or prohibition) may be useful during execution of such a task. 
Open Access This article is distributed under the terms of the Creative Commons Attribution 4.0 International License (http://creativecommons.org/licenses/by/4.0/), which permits unrestricted use, distribution, and reproduction in any medium, provided you give appropriate credit to the original author(s) and the source, provide a link to the Creative Commons license, and indicate if changes were made.

\section{References}

1. Ávila, Humberto. 2016. Certainty in law. Trans. Jorge Todeschini, Rev. Kevin Mundy. Cham: Springer.

2. Basinski, Sean, Candy Chang, John Mangin, and Rosten Woo. 2009. Vendor power! A guide to street vending in New York City. New York: The Center for Urban Pedagogy.

3. Bojarski, Marek, and Wojciech Radecki. 2016. Kodeks wykroczeń. Komentarz [Code of petty offences. A commentary], 7th ed. Warszawa: C.H. Beck.

4. Brunschwig, Colette R. 2001. Visualisierung von Rechtsnormen. Legal design. Zürich: Schulthess.

5. Castro, Cándida, Tim Horberry, and Francisco Tornay. 2004. The effectiveness of transport signs. In The human factors of transport signs, eds. Cándida Castro, and Tim Horberry, 49-69. Boca Raton: CRC Press.

6. Dudek, Michał. 2011. Paternalistic regulations expressed through means of visual communication of law? Contribution to another distinction of paternalistic legal regulations. In Argumentation 2011. International conference on alternative methods of argumentation in law. Conference proceedings, eds. Michał Araszkiewicz, Matěj Myška, Terezie Smejkalová, Jaromír Šavelka, and Martin Škop, 167-179. Brno: MUNI Press.

7. Dudek, Michał. 2015. „Nie samymi §łowami prawo żyje”—o prawie i wizualności [“Law does not live by word $\S$ alone" - on law and visuality]. In Wzajemne relacje prawa $i$ kultury [Mutual relationships of law and culture], ed. Ewa Średnicka, 37-71. Kraków: Wydawnictwo Kasper.

8. Dudek, Michał. 2015. Why are words not enough? Or a few remarks on traffic signs. In Problems of normativity, rules and rule-following, eds. Michał Araszkiewicz, Paweł Banaś, Tomasz GizbertStudnicki, and Krzysztof Płeszka, 363-372. Cham: Springer.

9. Golden, John M. 2016. Redundancy: When law repeats itself. Texas Law Review 94 (4): 629-711.

10. Horberry, Tim, Cándida Castro, Francisco Martos, and Patricie Mertova. 2004. An introduction to transport signs and an overview of the structure of this book. In The human factors of transport signs, eds. Cándida Castro, and Tim Horberry, 1-15. Boca Raton: CRC Press.

11. Kjørup, Søren. 2004. Pictograms. In Semiotik. Semiotics. Ein Handbuch zu den zeichentheoretischen Grundlagen von Natur und Kultur. A handbook on the sign-theoretic foundations of nature and culture. 4. Teilband. Volume 4, eds. Roland Posner, Klaus Robering, and Thomas A. Sebeok, 3504-3510. Berlin New York: Walter de Gruyter.

12. Kłodawski, Maciej. 2017. Redundancja $w$ tekście prawnym [Redundancy in legal text]. Toruń: Wydawnictwo Adam Marszałek.

13. Kotowski, Wojciech. 2010. Glosa do postanowienia Sądu Najwyższego z dnia 23 września 2009 r., sygn. I KZP 15/09, w sprawie postoju w strefie parkowania bez uiszczenia opłaty [Commentary on the decision of the Supreme Court of 23 September 2009, ref. no. I KZP 15/09, in the matter of parking in a parking zone without payment of fee]. Paragraf na Drodze [Paragraph on the Road] 2: $5-14$.

14. Kotowski, Wojciech. 2011. Prawo o ruchu drogowym. Komentarz [Road traffic law. A commentary], 3rd ed. Warszawa: Wolters Kluwer Polska.

15. Lansdown, Terry C. 2004. Considerations in evaluation and design of roadway signage from the perspective of driver attentional allocation. In The human factors of transport signs, eds. Cándida Castro, and Tim Horberry, 71-81. Boca Raton: CRC Press.

16. Mahler, Tobias. 2013. A graphical user-interface for legal texts?. In Internationalisation of law in the digital information society: Nordic yearbook of law and informatics 2010-2012, eds. Dan Jerker B. Svantesson, and Stanley Greenstein, 311-327. Copenhagen: Ex Tuto Publishing. 
17. Murat, Leszek. 2005. Normatywny charakter organizowania ruchu drogowego w Polsce $i$ USA (New Jersey). Studium legalności [Normative character of traffic organization in Poland and US (New Jersey). The study on legality]. Rzeszów: Wydawnictwo Oświatowe Fosze.

18. Murat, Leszek. 2012. Charakter prawny organizowania ruchu na drogach. Rzecz o tym, czym jest znak drogowy [Legal character of managing road traffic. This is what the road sign is about]. Transport Samochodowy [Car Transport] 2: 31-41.

19. Murat, Leszek. 2013. Kryptoprawotwórstwo administracyjne w zarządzaniu ruchem na drogach. Rzecz o tym, czym jest projekt organizacji ruchu [Administrative lawmaking in the road traffic management, what is traffic organization project]. Transport Samochodowy [Car Transport] 1: 27-46.

20. Murat, Leszek. 2013. Organizowanie ruchu na drogach w stanie Nowy Jork [Organizing the road traffic in the state of New York]. Transport Samochodowy [Car Transport] 1: 13-25.

21. Nutting, Charles B. 1964. Graphic law. American Bar Association Journal 50 (8): 780-781.

22. Polish Constitutional Tribunal's Judgment of 27 January 2004 (act sign. P 9/03).

23. Polish Law of 20 June 1997-Road Traffic Law-Journal of Laws 1997, no. 98, item 602 (Compilation Act-Journal of Laws 2017, item. 1260).

24. Polish Law of 20 May 1971-Code of Petty Offences-Journal of Laws 1997, no. 12, item 114 (Compilation Act-Journal of Laws 2015, item. 1094).

25. Polish Regulation of Ministers of Infrastructure and Internal Affairs and Administration of 31 July 2002 on the traffic signs and signals-Journal of Laws 2002, no. 170, item 1393.

26. Polish Regulation of Ministers of Transport, Construction and Maritime Economy and Internal Affairs of 3 October 2013 amending the Polish Regulation on the traffic signs and signals-Journal of Laws 2013, item 1325.

27. Polish Supreme Court's Decision of 23 September 2009 (act sign. I KZP 15/09).

28. Portella, Adriana. 2014. Visual pollution. Advertising, signage and environmental quality. Farnham: Ashgate.

29. Stefański, Ryszard A. 2005. Odpowiedzialność za nieprawidłowe zatrzymanie lub postój pojazdu [Responsibility for improper vehicle stopping or parking]. Paragraf na Drodze [Paragraph on the Road] 6: 16-27.

30. Stefański, Ryszard A. 2008. Prawo o ruchu drogowym. Komentarz [Road traffic law. A commentary], 3rd ed. Warszawa: Wolters Kluwer Polska.

31. Stefański, Ryszard A. 2010. Glosa do postanowienia SN z dnia 23 września 2009 r., sygn. I KZP 15/09 [Commentary on the Supreme Court Decision of 23 September 2009, file no. I KZP 15/09]. Prokuratura i Prawo [Public Prosecution and Law] 3: 148-160.

32. Studnicki, Franciszek. 1970. Traffic signs. Semiotica 2 (2): 151-172.

33. Tarapata, Szymon. 2012. Kontrowersje wokół wyznaczania granic dobra prawnego-uwagi na marginesie postanowienia Sądu Najwyższego z 23 września 2009 r. (sygn. akt I KZP 15/09) [Controversies over delimitation of legal good-marginal notes concerning Supreme Court's Decision of 23 September 2009 (act sign. I KZP 15/09)]. Czasopismo Prawa Karnego i Nauk Penalnych [Journal of Criminal Law and Penal Sciences] 1: 91-151.

34. UNECE. Road traffic and road signs and signals agreements and conventions. http://www.unece.org/ transport/international-agreements/transconventnlegalinst/list-of-agreements-for-tabs/road-traffic-androad-signs-and-signals-agreements-and-conventions.html. Accessed 8 Sept 2017.

35. Wagner, Anne. 2006. The rules of the road, a universal visual semiotics. International Journal for the Semiotics of Law 19 (3): 311-324.

36. Wagner, Anne. 2014. Game of power within the French urban landscape: A socio-legal semiotic analysis of communication, vision and space. International Journal for the Semiotics of Law 27 (1): $161-182$. 